\title{
Review on Phosphorus and Zinc Fertilizer Application for Enhanced Performance of Crops
}

\author{
Dugasa Gerenfes and Gobena Negasa \\ Ethiopian Institute of Agricultural Research, Kulumsa Agricultural Research Center, \\ Assela, Ethiopia. P.O.Box 489
}

\begin{abstract}
This review discusses about phosphorus and zinc fertilizer consumption led to increasing yield and yield components of the crops. The objectives of this review were focuses on the impact of application of phosphorus and zinc fertilizers on yield and yield components of crop plants and their importance on crop performance enhancement. The other important aspect of phosphorus and zinc nutrition is the interaction effect between them, especially in soils marginally deficient in phosphorus and zinc. When phosphorus and zinc were fertilized together, to such soils, crop yields are reported to increase with positive interaction of phosphorus and zinc. The Applications of zinc and phosphorus fertilizers led to increasing yield and yield components of crops such as height, number of tiller, Biomass yield, the number of filled grain spike, yield in ha, spike weight in plant, grain length, spike length in $\mathrm{m}^{2}$ and harvest index etc. Thus, it is important to apply the effect of $\mathrm{P}$ and $\mathrm{Zn}$ nutrients to improve yield and yield components of cops.
\end{abstract}

Keywords: Phosphorus, zinc, marginal, interaction

DOI: $10.7176 / \mathrm{JBAH} / 11-4-01$

Publication date: February $28^{\text {th }} 2021$

\section{Introduction}

Maximizing and stabilizing of agriculture plants yield are the main purposes of advanced agriculture one of the most important and limiting problems for developing a successful economical agriculture in nutrition elements deficiency. After nitrogen, phosphorus in comparison to the other nutrition essential elements has the most effect on both agricultural ecosystem and natural ecosystems (Saeed Mafi et al., 2013). Suitable plant nutrient increased assimilate production and photosynthesis efficiency at seed formation stage (Bagheri et al., 2000). High pH and low soil organic reduce root absorption and cause Zn deficiency in all dry regions of the world (Kanoni, 2001). Research on the optimum level of $\mathrm{P}$ and $\mathrm{Zn}$ fertilizially in pulse crop equal consumption fertilizers such as phosphorus fertilizer both cause of root development and speedy crop adult (Kumar 2004).

Phosphorus is an essential element for plants and animals. With regard to estimation, about 30 to $50 \%$ of increased food productions, Global in 1950 have been due to application of fertilizers including phosphorus consumption. Phosphorous is the major potentially yield limiting nutrient in which most soils are dominantly deficient in it (Miressa and Roborge, 1999), and among the micronutrients, $\mathrm{Zn}$ is widely reported to limit crop production and about 30 to $50 \%$ of world cultivated soils are considered deficient in $\mathrm{Zn}$. The deficiency of these nutrients becomes even more serious in alkaline calcareous dry soils. In these soils, $\mathrm{P}$ and $\mathrm{Zn}$ are mainly found as insoluble or plant unavailable forms, $\mathrm{P}$ fixed in apatite calcium minerals and $\mathrm{Zn}$ existing as insoluble zinc hydroxides and adsorbed strongly to carbonate minerals, such as calcite and dolomite (Cakmak et al., 1996).

The other important aspect of $\mathrm{P}$ and $\mathrm{Zn}$ nutrition is the interaction effect between them, especially in soils marginally deficient in $\mathrm{P}$ and $\mathrm{Zn}$. If $\mathrm{P}$ and $\mathrm{Zn}$ are fertilized together, to such soils, crop yields are reported to increase with positive interaction of $\mathrm{P}$ and $\mathrm{Zn}$ (Havlin et al., 2005). The requirement of $\mathrm{P}$ and $\mathrm{Zn}$ by fababean is relatively high. Fababean may require $\mathrm{P}$ and $\mathrm{Zn}$ fertilization in the range of 20 to $30 \mathrm{~kg} \mathrm{P}$ ha- 1 and 10 to $25 \mathrm{~kg} \mathrm{Zn}$ ha-1 (FAO, 2000). High P levels can affect soil properties such as (i) a shift in $\mathrm{pH}$ due to the dissolution of the fertilizer in soil solution or due to reaction of both the phosphate and the associated cation with soil components and (ii) changes in surface charge due to the adsorption of phosphate on the soil colloids (Shuman, 1988). Such changes in soil properties may influence the transformation of both native and applied $\mathrm{Zn}$ in soil in different forms and hence their availability to plants.

In addition to affecting $\mathrm{Zn}$ availability to plants, $\mathrm{P}$ fertilizers are an important anthropogenic factor of soil contamination with heavy metals (Singh, 1994). Concentration of heavy metals added to soil by P fertilizers depends on the origin of crude phosphates (Soler and Soler, 1996). Increased concentrations of As, $\mathrm{Cr}, \mathrm{Pb}, \mathrm{Hg}, \mathrm{Ni}$ and $\mathrm{Va}$ that can be found in $\mathrm{P}$ fertilizers are not as hazardous for human health as $\mathrm{Cd}$ because they may be highly toxic, even at very low concentrations (Jensen and Bro-Rasmussen, 1992).

Phosphorus element is an essential nutrient for crop growth and high yield with good quality. In this respect, Nasr-Alla et al., (1998) reported that increasing the rate of PK as single or in combined application increased number of branches/ plant, yield of pods/plant and per fad of peanut. In addition, El-far and Ramadan (2000) indicated that application of $46.6 \mathrm{~kg} \mathrm{P}_{2} \mathrm{O}_{5} / \mathrm{fad}$ and $36 \mathrm{~kg} \mathrm{~K} 2 \mathrm{O} /$ fad gave the highest effect on yield and its attributes. Similarly, Ali and Mowafy (2003) found that adding phosphorus fertilizer caused significant increase in seed yield 
and all their attributes. Recently, El-Habbasha et al., (2005) reported that increasing phosphorus levels increased each of leaves and stem weight/plant, number of pods and seeds/plant, weight of pods and seeds /plant, 100-seed weight, seed and oil yields, oil percentage, seed protein content as well as NPK contents.

The zinc is a micro element that in little amount is required for crop plant, but its importance in production of agricultural plant has been increased in recent years. Zinc is considered as the most limiting micro element in production of crop plant in different parts of the world. Dafi (2007) reported that the 30\% decreasing in wheat, rice, corn and the other eatable crop plants yield are common even in soils with zinc mild deficiency. About 50\% of cultivated soils world are available for plants, for producing grain with little amount of zinc (Saeed Mafi et al., 2013).

The sandy texture soils are characterize very low organic matter low water holding capacity and high nutrient leaching losses; The occurrence of Zn deficiency in semiarid regions. It is well known that such soil factors are known to limit mobility and availability of soil-Zn or fertilizer-Zn to plant roots. Therefore, zinc deficiency is a common feature in many climatic regions, particularly in sandy soil and it causes severe decreases in yield and quality of crops (Marschner, 1993). In general, zinc and phosphorus fertilizers consumption led to increasing yield and yield components of crops such as height, number of tiller, Biomass yield, the number of filled grain spike, yield in ha, spike weight in plant, grain length, spike length in $\mathrm{m}^{2}$ and harvest index etc. Thus, it is important to study the effect of $\mathrm{P}$ and $\mathrm{Zn}$ nutrients and their interaction on yield components and yield potential of crops. To review this paper, secondary data type have been used by reviewing text books, theses, and internet Google was used to get research done on phosphorus and zinc fertilizers and their effect on yield and yield components of crops.

\section{Objective of this Review Paper:}

$\$$ To review the impact of application of phosphorus and Zinc fertilizers on yield and yield components of crop plants.

* To share information on the effect of phosphorus and zinc on enhancing yield of crops and yield components of crops.

* To review on importance of phosphorus and zinc in crop plants.

\section{Role and Importance of Phosphorus and Zinc Fertilizers in Crop Plants \\ 2.1. Role of phosphorus in plant growth and development}

Phosphorus (P) is an important plant macronutrient, making up about $0.2-0.5 \%$ of a plant's dry weight and it is second to $\mathrm{N}$ as the most limiting element for plant growth (Bieleski, 1973). It is a component of key molecules such as nucleic acids, phospholipids, and ATP, and, consequently, plants cannot grow without a reliable supply of this nutrient. Phosphorus enters the plant through root hairs, root tips, and the outermost layers of root cells (Brady and Weil, 2002).

It is vital for numerous metabolic processes both in plant and animal tissue. Among the significant functions and qualities of plants on which phosphorus has an important effects are: it enhances many aspects of plant physiology, including the fundamental processes of photosynthesis, reproduction, flowering, fruiting (including seed production) and maturation; root growth, particularly development of lateral roots and fibrous rootlets, is encouraged several key plant structure compounds and as a catalysis in the conversion of numerous key biochemical reactions in plants by phosphorus (Brady and Weil, 2002). Phosphorus has also very positive effects on nodule formation and nitrogen fixation in legume crops (Togay et al., 2008) and promotes more uniform and earlier crop maturity, improves seed quality, and increases resistance to plant diseases.

Phosphorus is essentially an immobile nutrient and continued application of phosphate fertilizers tends in time to increase the levels of this nutrient in the soil and particularly its level in the labile forms that can release phosphorus to the soil solution. Deficiency of these nutrients results in stunted shoot and root growth due to reduced cell division and reduced cell enlargement. No soil can sustain high yields if it is deficient in $\mathrm{P}$ (Rao et al., 1999). Phosphorus is one of the essential macronutrients required by plants. As an essential plant nutrient, $\mathrm{P}$ is involved in a wide range of plant processes from permitting cell division to the development of a good root system to ensuring timely and uniform ripening of the crop. $\mathrm{P}$ is needed most by young, fast-growing tissues, and performs a number of functions related to growth, development, photosynthesis, and utilization of carbohydrates (Rao, 1996).

Phosphorus is a constituent of Adenosine Diphosphate (ADP) and adenosine triphosphate (ATP), two of the most important substances in life processes. ATP is a source of energy for physiological processes such as biological nitrogen fixation (Giller, 2001), photosynthesis, respiration, energy storage and transfer, cell division, cell enlargement, root development, flowering, seed formation, fruiting and improvement of crop quality (Uchida, 2000; Sara et al., 2013). Because of the importance of P for plant growth and yield, many compound fertilizers (NPK) used to correct major deficiencies in soil contain $\mathrm{P}$ as a major element.

Optimal plant growth requires $\mathrm{P}$ in the range of $0.3-0.5 \%$ of dry matter during the vegetative growth stage. Dry matter $\mathrm{P}$ contents in excess of $1 \%$ may be toxic for most crops. The partial productive efficiency of $\mathrm{P}$ for grain 
or seed is higher at early growth stages than at later stages, because $\mathrm{P}$ is needed for tillering or branching. If sufficient $\mathrm{P}$ is absorbed at early growth stages, it will be redistributed to other growing organs. Plant roots acquire $\mathrm{P}$ as phosphate, primarily in the form of $\mathrm{H}_{2} \mathrm{PO}_{4}^{-}$, from the soil solution (Vance et al., 2003). The concentration of $\mathrm{H}_{2} \mathrm{PO}_{4}{ }^{-}$in the soil solution is often low $\left(2\right.$ to $10 \mu \mathrm{M}$ ) (Raghothama, 1999) and, consequently, the supply of $\mathrm{H}_{2} \mathrm{PO}_{4}{ }^{-}$ to the root surface by diffusion is slow. Therefore, $\mathrm{P}$ is one of the most unavailable and inaccessible macronutrients in the soil (Vance et al., 2003) and frequently limits plant growth. For this reason, application of inorganic $\mathrm{P}$ fertilizers of low fertility soils enhances crop productivity. Site-specific $\mathrm{P}$ application to lower testing regions may be a more profitable approach, although identifying lower P regions within fields is a challenge. With increasing demand of agricultural production, phosphorus is receiving more attention as a non-renewable resource (Cordell et al., 2009).

\subsubsection{The role of phosphorus in biological nitrogen fixation}

Phosphorus is one of the essential nutrients for legume growth and BNF (Mhango et al., 2008). Phosphorus deficiency can limit nodule number, leaf area, and biomass and grain development in legumes. Symbiotic nitrogen fixation has a high P demand because the process consumes large amounts of energy (Schulze et al., 2006) and energy generating metabolism strongly depends upon the availability of P (Plaxton, 2004). Phosphorous affects root development and hence uptake of nutrients and water. Phosphorus, apart from its effect on the nodulation process and plant growth, has also been found to exert some direct effects on soil Rhizobia. Singh and Sale (2000) reported that $\mathrm{P}$ fertilization stimulates root growth, photosynthesis and increases hydraulic conductibility of roots. Low $\mathrm{P}$ availability in soils results in a decrease in shoot growth, affects the photosynthetic activity, and limits the transport of photosynthates to nodules with significant decline in $\mathrm{N}_{2}$ fixation by the plant (Israel, 1987).

The biological system needs energy which provides hydrogen reductant and also the energy for ATP system in nitrogenase reactions. In Malawi, low yield of legumes grown by smallholder farmers may be strongly linked to minimal use of $P$ fertilizer (Mwalwanda et al., 2003) among other factors, and this was also identified in studies on the response of maize to legumes and $\mathrm{N}$ fertilizer in central Malawi (Robertson et al., 2005). Studies have shown that there are benefits of P fertilization in legume cropping systems. Giller (2001) reported that the application of P fertilizer can overcome the deficiency in soils that do not strongly adsorb P. Given the high variability of soil fertility in smallholder farming systems, soil testing remains the most precise available tool to: Determine whether P deficiencies are the cause of low soybean yields, and Prescribe adequate P fertilization rates (Melgar et al., 1995).

Nitrogen is reduced to $\mathrm{NH}_{3}$ under consumption of ATP and redox equivalents, and is associated with the formation of $\mathrm{H}_{2}$ as a by-product. Thus, adding $\mathrm{P}$ fertilizer may reduce stress in the symbiotic relation between root bacteria and legume plant by providing this energy. The enzyme that catalyses the reaction is called nitrogenase and consists of the dinitrogenase reductase protein ( $\mathrm{Fe}$ protein) and the dinitrogenase (MoFe protein) which actually catalyses the reduction of $\mathrm{N}_{2}$.

\subsubsection{The role of Phosphorus in root nodule formation (Nodulation)}

Biological nitrogen fixation (BNF) is the process in which nitrogen gas $\left(\mathrm{N}_{2}\right)$ from the atmosphere is incorporated into the tissue of legume plants, with the help of soil microorganisms. It is the symbiosis relationship that results in the formation of a specialized structure called nodule. The bacterial micro symbiont fixes nitrogen for macrosymbiont which is the legume plant in return for reduced carbon (C) from the plant host to the micro symbiotic which is the rhizobia bacteria (Gyaneshwar et al., 2002).

Leguminous plants are able to fix atmospheric $\mathrm{N}_{2}$ through the association with rhizobia. The legume plant supplies the carbohydrate for bacterial growth while the bacteria fix atmospheric $\mathrm{N}_{2}$ into $\mathrm{NH}_{4}{ }^{+}$, to be converted into amino acids that can be used by the plant to synthesize proteins for its growth and development (Russell, 2008). Symbiotic association is a highly specified relationship between the host plant and the bacteria. Rhizobiumlegume symbiosis involves the interaction between the plant and the bacteria leading to initiation and development of the root nodules. Soil bacteria like Rhizobium live in nodules as nitrogen fixing bacteroids.

Phosphorus influences nodule development through its basic functions in plants as an energy source. Phosphorus plays a vital function in increasing plant tip and root growth, decreasing the time needed for developing nodules to become active and of benefit to the host legume. Furthermore, $\mathrm{P}$ increases the number and size of nodules and the amount of nitrogen assimilated per unit weight of nodules, increasing the percent and total amount of nitrogen in the harvested portion of the host legume and improving the density of Rhizobium bacteria in the soil surrounding the root (Bashir et al., 2011). Phosphorus brings about the ability of catalyzing stress in the symbiotic relation between root bacteria and legume plants (Tsvetkova et al., 2003).

The optimum $\mathrm{pH}$ for root nodule bacterial growth is considered to be between 6.0 and 7.0 and relatively few root nodule bacteria grow well at $\mathrm{pH}$ less than 5. Aluminum and Manganese toxicities are likely to be encountered in many tropical soils with $\mathrm{pH} 4.5$ or less. Both plant roots and nodulation are adversely affected. Nodule formed in leguminous plants shows a typical healthy and effectiveness by showing a pink or red color and is brought about by formation of protein called leg hemoglobin0 (Graham et al., 1994). 


\subsubsection{Availability of Phosphorus in Soil}

Phosphorus (P) which is the second most important element for crop production had threefold problem in soil fertility (FAO, 2000). First, the total P level in the soil is low (200 to $3000 \mathrm{~kg} \mathrm{P}$ in the upper $15 \mathrm{~cm}$ depth of soil of 1 ha of land, on the average $1000 \mathrm{~kg}$ P). Secondly, P compounds commonly found in soils are mostly unavailable to plant uptake, often because they are highly insoluble. Thirdly, when soluble sources of $\mathrm{P}$, such as those in fertilizers and manures are added to the soil, they are fixed, in time, forming highly insoluble compounds of $\mathrm{P}$ (Brady and Weil, 2002).

About $80 \%$ of the $\mathrm{P}$ becomes immobile and unavailable for plant uptake due to adsorption, precipitation or conversion to organic form thus phosphate is very stable insoluble and only a very small proportion exists in the soil solution. Moreover, the availability of $\mathrm{P}$ from fertilizer may be affected by the soil reaction, the degree of soil deficiency, rate and method of application, needs of the specific crops and certain soil differences. Under low $\mathrm{N}$ fertilizer inputs, soil $\mathrm{P}$ availability is usually the major factor limiting the rate of $\mathrm{N}_{2}$ fixation in legume crops (Toro et al., 1998) and, in the absence of AMF (Arbuscular Mycorrhizal Fungi) infection, supplementary phosphorus fertilization is generally necessary for the maintenance of $\mathrm{N}_{2}$ fixation rates by Rhizobium at the levels required for economically viable crop production (Andrade et al., 1998).

The response to applied $\mathrm{P}$ was more pronounced on soils which are low in available phosphorus as compared with other soils. Plants supplied with adequate amount of $\mathrm{P}$ were reported to form good root system, strong stem, mature early and give high yield. In contrast, plants grown on P deficient soils showed stunted growth, low shoot to root ratio, poor fruit and seed formation, purple colored leaves with reddish coloration of stem. Phosphorus availability is seldom adequate for optimal plant growth. Phosphorus is commonly bound to many soil constituents, forming complexes of limited availability to plants (Sample et al., 1980). Therefore, low phosphorus availability is a primary constraint to terrestrial plant productivity, and is often acutely limiting in the tropics and sub-tropics. Phosphorus availability is greatest at soil $\mathrm{pH}$ values between 6 and 7. Immobilization of inorganic $\mathrm{P}$ by these processes renders a portion of the added $\mathrm{P}$ unavailable for plant uptake. Generally, soil $\mathrm{pH}$ is the main property controlling inorganic $\mathrm{P}$ forms, although $\mathrm{Al}, \mathrm{Fe}, \mathrm{Mn}$ and $\mathrm{Ca}$ contents determine the amount of these forms (Sharpley, 2000). According to Sharpley (2000), topsoil P content is usually greater than in subsoil, due to the sorption of added $\mathrm{P}$ and greater biological activities and accumulation of organic materials.

\subsubsection{Factors Affecting Phosphorus Availability}

Factors influencing $\mathrm{P}$ availability include temperature, compaction, moisture, aeration, and soil $\mathrm{pH}, \mathrm{P}$ fixation by soil colloids, and type and amount of nutrients (including P) status of soil. For example, decreasing the contents of soil water and $\mathrm{O}_{2}$ to below the optimum levels reduces $\mathrm{P}$ uptakes. Fixation limits the $\mathrm{P}$ availability, which causes deficiency in most agricultural soils (FAO, 2000). On the other hand, an increase in temperature generally decreases the availability of inorganic $P$. This is why soils in warm regions of the world are generally much greater fixers of $\mathrm{P}$ than the soils of the cooler regions. One of the main crop factors influencing $\mathrm{P}$ uptake is the type and/or extent of root system in the P enriched topsoil layer (Prasad and Power, 1997).

The plant available $\mathrm{P}$ is usually in inorganic forms, which are almost exclusively the orthophosphate ions $\left(\mathrm{H}_{2} \mathrm{PO}_{4}^{-}, \mathrm{HPO}_{4}^{-2}\right.$ and $\left.\mathrm{PO}_{4}^{-3}\right)$ occurring in the soil solution. The relative abundance of these ionic forms is largely dependent on the soil $\mathrm{pH}(\mathrm{FAO}, 2000)$. Of these, the most accessible or primary, with the greatest activity coefficient, followed by the secondary ion $\mathrm{HPO}_{4}^{-2}(\mathrm{FAO}, 2000)$. At intermediate $\mathrm{pH}$ value $(\mathrm{pH}=7.2), \mathrm{H}_{2} \mathrm{PO}_{4}{ }^{-}$and $\mathrm{HPO}_{4}^{-2}$ may be present simultaneously in equal amounts whereas below and above this $\mathrm{pH}, \mathrm{H}_{2} \mathrm{PO}_{4}^{-}$and $\mathrm{HPO}_{4}^{-2}$ are the predominant forms of available $\mathrm{P}$, respectively.

\subsubsection{Phosphorus Use Efficiency}

Nutrient use efficiency is receiving a great deal of attention now a days because of increasing fertilizer costs associated with natural gas costs and growing pressure for agriculture to minimize negative environmental impacts. Apparent nutrient recovery (increase in uptake per unit nutrient added), agronomic efficiency (crop yield increase per unit nutrient added) and physiological efficiency (grain yield increase per unit $P$ accumulated) are useful terms. Usually P Use Efficiency (PUE) of various crops is known to be low and recovery in the year of application varying between $15-25 \%$ (Nisar, 1985) because of high fixation capacity of the soil. The various reactions of applied P in the soil resulting in formation of compounds that become less available to plants are considered as one of the factors attributing to low P recovery (Delgado et al., 2002). Because of the substantial residual effect of $\mathrm{P}$ fertilization on the $P$ nutrition of future crops, first year recovery of $P$ by the crop will usually greatly underestimate P use efficiency (Loneragan, 1978).

According to (Amsalu et al., 2016) reported, highly significant effects of the variety and P application on shoot and pod P concentrations were recorded and $\mathrm{p}$ grain concentration was affected only by variety. PUE was significantly affected by variety, but $\mathrm{P}$ application had no significant effect. Although not significant, application of $30 \mathrm{~kg} \mathrm{P} \mathrm{ha}^{-1}$ reduced average PUE(phosphorus Use Efficiency) of fababean plants from $224.4 \mathrm{~kg}$ grain $\mathrm{kg}^{-1} \mathrm{P}$ $(0 \mathrm{P})$ to $202.9 \mathrm{~kg}_{\text {grain }} \mathrm{kg}^{-1} \mathrm{P}(30 \mathrm{P})$. PUE was significantly positively correlated with GDY (grain dry yield) and significantly negatively correlated with P concentrations in shoot, grain, and shoot PAE (Phosphorus acquisition efficiency) (Amsalu et al., 2016). Reduced P sink strength of pods and certainly of grains may therefore be an 
additional PUE parameter in further PUE studies involving grain legumes. Thus, under low P conditions grain yield is higher. Rose and Wissuwa (2012) also argue that targeting genotypes for low grain P can improve PUE of the system.

According to research conducted on wheat crop, Phosphorus use efficiency (PUE) of wheat indicated that lower PUE was seen at higher $\mathrm{P}$ rates application. The maximum PUE of $31.20 \mathrm{~kg} \mathrm{~kg}^{-1} \mathrm{P}_{2} \mathrm{O}_{5}$ was observed at 150 $\mathrm{kg} \quad \mathrm{P}_{2} \mathrm{O}_{5} \mathrm{ha}^{-1}$, and it decreased significantly at higher Phosphorus rates application (250 kg $\left.\mathrm{P} 2 \mathrm{O} 5 \mathrm{ha}^{-1}\right)$ (Ghafoor,2016). These results were in agreement with finding by Rahim et al., (2010); they found that PUE of wheat decreased significantly at higher Phosphorus rate.

\subsubsection{The Role of Phosphorus on Crop Yield and Yield Components}

Phosphorus is the second most crop-limiting nutrient in most soils. It is second only to nitrogen in fertilizer use. Plant growth behavior is influenced by the application of phosphorus (Kaya et al. 2001). It is needed for growth, utilization of sugar and starch, photosynthesis, nucleus formation and cell division, fat and albumen formation. Energy from photosynthesis and the metabolism of carbohydrates is stored in phosphate compounds for later use in growth and reproduction (Ayub et al. 2002). It is readily translocate within the plants, moving from older to younger tissues as the plant forms cells and develops roots, stems and leaves (Ali et al. 2002).

Adequate $\mathrm{P}$ results in rapid growth and earlier maturity and improves the quality of vegetative growth. Phosphorus deficiency is responsible for crooked and missing rows as kernel twist and produce small ears nubbins in maize. Its deficiency is widespread in $90 \%$ of the Pakistani soils and the application of phosphatic fertilizers is considered essential for crop production and its deficiency will slow overall plant growth (Rashid and Memon, 2001). Ali et al. (2002) reported significant effect of $P$ application on grain yield; whereas Ayub et al. (2002) observed significant effect of $\mathrm{P}$ application on dry matter yield and individual plant characteristics like height, number of leaves and leaf area. Tariq et al (2011) reported that, phosphorus at the rate of $100 \mathrm{~kg} \mathrm{ha}^{-1}$ has the best performance in obtaining maximum grain yield of maize. As this report, $\mathrm{P}$ at the rate of $100 \mathrm{~kg} \mathrm{ha}^{-1}$ is highly recommended for optimum grain yield of maize. According to Yirga et al (2012), Phosphorus fertilization showed significant differences in fababean's pods per plant, seeds per pod, and number of branches per plant at maturity, and plant height both at 50\% flowering and maturity stage. The yield advantage of fababean by applying P could be attributed to an increase in the number of productive nodes and number of pods per plant. In fact, the number of pods per fababean plant was found to correlate strongly with grain yield (Yemane and Skjelvg, 2003).

Dania Stephen et al., (2014) reported that, the application of $\mathrm{P}$ at the rate of $25 \mathrm{~kg} \mathrm{ha}^{-1}-75 \mathrm{~kg} \mathrm{ha}^{-1}$ significantly improved the growth, yield, nodulation and nutrient uptake of pigeon pea. The application of small quantity of $\mathrm{P}$ at the rate of $36 \mathrm{~kg} \mathrm{ha}^{-1}$ significantly increased the growth, yield and nodulation of pigeon pea. It has been reported that the application of $26.4 \mathrm{~kg} \mathrm{P}^{-1}$ significantly improved seed yield, nodulation and nitrogenase activity in pea (Kasturi, 1995). Also, it was reported that the application of $17-43 \mathrm{~kg} \mathrm{P}^{-1}$ significantly improved the growth and yield of C. cajan in nutrient depleted soil (Ahlawat, 1993).

Table 1: Effect of different levels of phosphorus on plant height $(\mathrm{cm})$, number of cobs plant ${ }^{-1}$, number of grains $\mathrm{cob}^{-1}$,thousand grain weight, biological yield and grain yield of maize

\begin{tabular}{|c|c|c|c|c|c|c|c|}
\hline 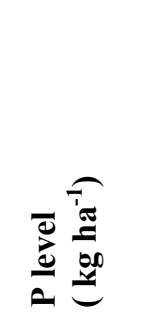 & 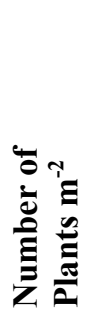 & 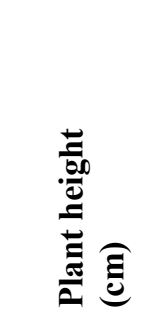 & 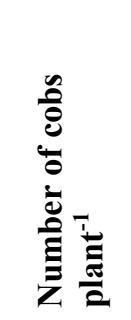 & 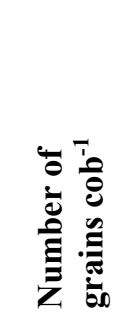 & 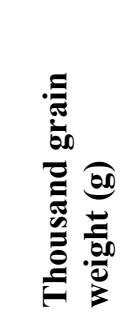 & 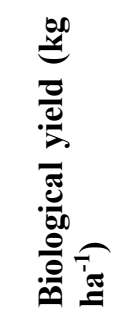 & 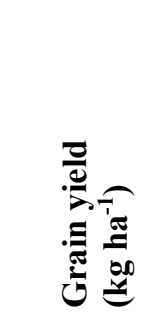 \\
\hline 0 & 4 & $146 b$ & $0.86^{c}$ & $290^{\mathrm{b}}$ & 188 & 5754 & $1305^{\mathrm{c}}$ \\
\hline 50 & 5 & $151 \mathrm{ab}$ & $0.97 \mathrm{a}$ & $315^{\mathrm{a}}$ & 210 & 5936 & $1816^{\mathrm{bc}}$ \\
\hline 100 & 6 & $158 \mathrm{a}$ & 1.19 & $327 \mathrm{a}$ & 241 & 5999 & $2415 \mathrm{a}$ \\
\hline 150 & 6 & $153 \mathrm{ab}$ & $1.02 \mathrm{~b} .1$ & $320 \mathrm{a}$ & 220 & 6454 & $2027 \mathrm{ab}$ \\
\hline 200 & 5 & $147 \mathrm{~b}$ & $0.96 b$ & $312 a$ & 219 & 7130 & $1930 \mathrm{ab}$ \\
\hline $\operatorname{LSD}(0.05)$ & NS & 7.14 & 0.103 & 15.81 & NS & NS & 594.3 \\
\hline
\end{tabular}

Means not sharing a letter differ significantly by LSD at $5 \%$ probability level (Tariq M., 2011).

Salem and El-Nakhlawi (1987) found that increasing of phosphorus fertilizer had not any effect on yield component of broad bean and it just affected the branch number. In an experiment on Zea mays L. was proved that increasing of phosphorus until $80 \mathrm{~kg} \mathrm{ha}^{-1}$ increased significantly yield, weight of 100 seeds and percent of seed protein (2002). Majumdar et al (1994) found that increasing of sulfur, phosphorus and zinc caused the significant increase on seed yield, nitrogen concentration, sulfur and phosphorus in seeds, stem and leaves of broad bean. Nitrogen and Phosphorous uptake could be enhanced with increased P applications (Jiang et al., 2006). Chaturvedi (2006) found that $28.5 \mathrm{~kg} \mathrm{P} \mathrm{ha}^{-1}$ as optimum for growth, plant height, tillers, grains spike 1000 grain weight, grain and straw yields. Jiang et al. (2006) observed that $108 \mathrm{~kg} \mathrm{P} \mathrm{ha}^{-1}$ for higher leaf area index, tillers, ear bearing tillers 
and dry matter accumulation. Khalid et al. (2004) applied $45 \mathrm{~kg} \mathrm{P} \mathrm{ha}^{-1}$ in wheat and obtained maximum emergence, productive tillers, grain yield and biological yield in crop plants. Seid et al., (2015) indicated that, the application of phosphorus fertilizer had significantly affected all of the yield and yield components of such as plant height, number of branches per plant and number of pods per plant in chickpea.

The application of $60 \mathrm{~kg} \mathrm{P}_{2} \mathrm{O}_{5}$ had resulted better performance in all of the parameters of yield and yield components for chickpea. Mung bean plants showed significant variation in respect of plant height, number of branches plant ${ }^{-1}$, number of pods plant ${ }^{-1}$, number of seeds pod ${ }^{-1}$, Pod length, weight of 1000 -seeds, seed yield ( $t$ $\left.\mathrm{ha}^{-1}\right)$ and stover yield $\left(\mathrm{t} \mathrm{ha}^{-1}\right)$ when phosphorus in different doses were applied. Plant height, number of branches plant $^{-1}$, number of pods plant ${ }^{-1}$, and number of seeds pod $^{-1}$, Pod length and weight of 1000 -seeds were increased with P levels from 0-20 $\mathrm{kg} \mathrm{ha}^{-1}$ (Rahman et al., 2015).

At Gedo, the grain yield of barley was significantly affected by $\mathrm{N}$ application, the application of $10 \mathrm{~kg} \mathrm{ha}^{-1} \mathrm{~N}$ resulted in a better grain yield $\left(2469 \mathrm{~kg} \mathrm{ha}^{-1}\right)$ than the control and other $\mathrm{N}$ rates. Nevertheless, the combined application of NP at a rate of $10 / 30 \mathrm{~kg} /$ ha resulted in the highest yield .At Shambo, the grain yield of barley was significantly $(\mathrm{P}<0.05)$ affected by $\mathrm{P}$ application but not by $\mathrm{N}$ or $\mathrm{N} \times \mathrm{P}$ interactions. The application of $20 / 30 \mathrm{~kg} \mathrm{ha}^{-}$ ${ }^{1} \mathrm{~N} / \mathrm{P}$ doubled the barley grain yield compared with the unfertilized (BARC, 2006).

Table 2 Effect of NP fertilizers on barley yield and yield components

\begin{tabular}{|c|c|c|c|c|c|c|c|c|c|c|}
\hline & 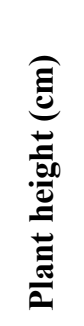 & 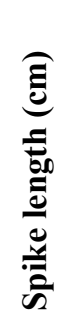 & 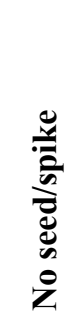 & 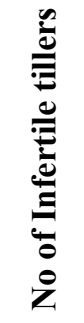 & 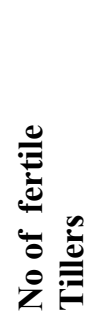 & 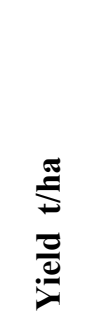 & 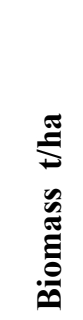 & 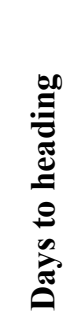 & 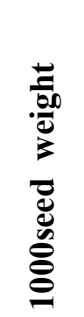 & 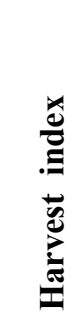 \\
\hline $0 / 0$ & 61.3 & 6.3 & 36.3 & 34.5 & 253.6 & 0.86 & 2.4 & 65 & 52.4 & 9.3 \\
\hline $23 / 10$ & 69.6 & 6.3 & 37.8 & 31.5 & 241.1 & 0.106 & 2.6 & 60 & 53.2 & 13.0 \\
\hline $46 / 20$ & 74.8 & 6.3 & 39.5 & 12.6 & 300.6 & 1.77 & 3.2 & 52 & 54.1 & 14.2 \\
\hline $69 / 30$ & 83.1 & 6.6 & 42.6 & 15.8 & 338.0 & 2.02 & 3.9 & 55 & 54.8 & 15.5 \\
\hline $\begin{array}{l}\text { LSD } \\
(0.05 \%)\end{array}$ & 8.5 & 0.5 & 7.0 & 42.3 & 73.4 & 2.3 & 0.4 & 15.4 & 5.2 & 6.9 \\
\hline CV $(\%)$ & 9.6 & 7.8 & 14.8 & 45.5 & 16.2 & 17.2 & 12.5 & 13.2 & 5.6 & 14.8 \\
\hline
\end{tabular}

Source:Mesfin and Zemach, 2015.

According to (Mesfin and Zemach, 2015) report indicated that nitrogen and phosphorus fertilizer showed no significant effect on number of days to heading while number of fertile tillers, total biomass and yield were significantly increased by application of nitrogen and phosphorus. However, the effects of nitrogen and phosphorus were significant $(\mathrm{P}<0.05)$ on plant height, spike length, number of seeds per spike and grain yield. It was generalized that, grain yield tended to be higher under NP $69 / 30 \mathrm{~kg} \mathrm{ha}^{-1}$ treatment $(2.02 \mathrm{t} / \mathrm{ha})$. In contrast, the lowest grain yield $(0.86 \mathrm{t} / \mathrm{ha})$ was obtained from $0 / 0 \mathrm{NP}$ treatment, although the interaction effects of nitrogen and phosphorus were significant on treatments with varieties and balanced amount of nitrogen and phosphorus. Furthermore, the increment in yield due to phosphorus fertilizer may be attributed to the activation of metabolic processes, where its role in building phospholipids and nucleic acid in known. El-Habbasha et al (2005) reported that increasing phosphorus levels increased each of number of pods and seeds/plant, weight of pods and seeds/ plant, 100-seed weight as well as seed and oil yields.

According to Ghafoor (2016) reported, the plant height of wheat was affected by various $\mathrm{P}$ application rates. The report indicated that, there was a significant difference between both of $200 \mathrm{~kg} \mathrm{p}_{2} \mathrm{O}_{5} / \mathrm{ha}$ and $250 \mathrm{~kg} \mathrm{P} 2 \mathrm{O} 5 / \mathrm{ha}$ with the control treatment and the plant height was increased from $104.30 \mathrm{~cm}$ to $112.30 \mathrm{~cm}$ from control $(0 \mathrm{~kg}$ $\mathrm{p} 205 / \mathrm{ha}$ ) to $250 \mathrm{~kg} \mathrm{p}_{2} 0_{5} / \mathrm{ha}$, respectively. These results were in confirmation with the findings of Alam et al., (2003), who reported that the plant height significantly increased with increasing of application rates of phosphorus fertilizer to the soil. According to the research conducted on wheat crop, data analysis for 1000- grain weight of wheat showed that there was a significant difference between and both $0 \mathrm{~kg} \mathrm{p}_{2} \mathrm{O}_{5} / \mathrm{ha}$ and $150 \mathrm{~kg} \mathrm{p} 205 / \mathrm{ha}$ at $(\mathrm{P} \leq$ 0.05) which were identical with those proposed by Rahim et al., (2010) that, they found that 1000-grain weight of wheat increased significantly with increasing $P$ rate application.

The Biological yield of wheat was also influenced by various $\mathrm{P}$ application rates significantly. As it was reported, there was a significant difference between $200 \mathrm{~kg} \mathrm{p}_{2} 0_{5} / \mathrm{ha}$ and both $0 \mathrm{~kg} \mathrm{p}_{2} 0_{5} / \mathrm{ha}$ and $150 \mathrm{~kg} \mathrm{p} 205 / \mathrm{ha}$ at $(\mathrm{P} \leq 0.05)$ for wheat (Ghafoor, 2016). These results confirm the findings of Pawel (2013), who indicated that the biological yield production of winter wheat increased with $\mathrm{P}$ fertilizer rate applications compared to the control. Another most important yield determinant is the number of spike per square meter which is affected by various factors including balanced nutrition. It was indicated that, the number of spike per square meter was affected by $\mathrm{P}$ 
application rate (Ghafoor, 2016); which were congruent with the finding by El-Gizawy (2009), who deducted that the spikes $/ \mathrm{m}^{2}$ is increased by increasing $\mathrm{N}$ and $\mathrm{P}$ fertilizer level applications.

\subsection{The Role and Importance of Zinc in crop Plants}

In calcareous soils solubility of micronutrients is far less due to high $\mathrm{pH}$, and this reduces ability of nutrient uptake by plants and naturally plants requirement increases to these elements (Alloway, 2008). Also excess use of phosphate fertilizers in soils with micronutrients deficiencies causing imposed deficiency of micronutrients in the plants. Accordingly concentration of micronutrient will decline in dry matter and crop yield (Salimpour et al., 2010). With increasing utilization of chemical fertilizer and on the other hand increasing fertilizer prices due to their dependence on fossil fuels, water, air and soil pollution and ignorance in the use of chemical fertilizers are problems that must be solved with appropriate methods (Alloway, 2008). Today in the world, policy of reduce utilization of chemical fertilizers, pesticides, and efficient use of inputs is considered to reduce environmental risk and provided human health. Zinc is essential element for crop production and optimal size of fruit, also it required in the carbonic enzyme which present in all photosynthetic tissues, and required for chlorophyll biosynthesis (Ali et al., 2008).

Zinc is needed modicum but critical concentrations and if the amount available is not adequate, plants and animals will suffer from physiological stress brought about by the dysfunction of several enzyme systems and other metabolic functions in which zinc plays a part (Alloway, 2008). By utilizing of fertilizers contain zinc and other micronutrients, performance on quality of crops is increasing and with shortage of this elements due to decline in plant photosynthesis and destroy RNA, amount of solution carbohydrates and synthesis of protein decreased and then performance and quality of crop will be decreased (Mousavi et al., 2007). Mousavi and colleagues in a study (2007) reported that utilization of zinc from resource zinc sulfate increased efficiency and quality of potato crop. Phosphorus is the important element that interferes on zinc uptake, as zinc uptake by plants reduces by increasing phosphorus in soil (Salimpour et al., 2010).

Zinc uptake of soil solution in divalent cations form $\left(\mathrm{Zn}^{2+}\right)$; in calcareous soils with high $\mathrm{pH}$ zinc uptake may be a valence ion form (Alam et al., 2010; Alloway, 2008). In the xylem routes zinc is transmitted to divalent form or with organic acids bond. In the phloem sap zinc makes up complex with organic acids with low molecular weight, and increases its concentration. Zinc is in plants only in divalent cation $\left(\mathrm{Zn}^{+2}\right)$ and does not participate in oxidation and regenerative reactions. The main functions of zinc is tendency to make up tetragonal complexes with nitrogen, oxygen and sulfur, thus zinc have a catalytic, building and activating role in the enzymes (Alloway, 2008).

\subsubsection{Zinc in Soil}

Total value of zinc in soil is depends to chemical composition of raw materials in the soil. Zinc value of earth's crust is $80 \mathrm{mg} / \mathrm{kg}$ approximately, and its value in soil is usually 10 to $300 \mathrm{mg} / \mathrm{kg}$ with an average of $50 \mathrm{mg} / \mathrm{kg}$. Zinc is in different forms in the earth's crust, such as sulfate, silica and carbonate minerals. Also zinc is in different forms in the soil as water-soluble, exchange, connected to organic matter and stabilized by the secondary clay minerals (Alloway, 2008).

Zinc deficiency related to soils $\mathrm{pH}$ and its value is very low in calcareous soils with high $\mathrm{pH}$ (Alam et al., 2010; Alloway, 2008). Zinc mobility and uptake in soil is dependent on many factors such as soil acidity, zinc total value in the soil, organic matter and soil type. The most important factors affecting on the zinc usability can be noted as due to: Zinc total value maybe very low in highly acidic soils due to the intense soil leaching, Zinc usability decreases by increasing soil $\mathrm{pH}$, because the minerals solubility reduced and zinc uptake increases by soil colloidal particles such as clay minerals, iron and aluminum oxides, organic matter and calcium carbonate, Zinc usability decreases by decreasing temperature and light intensity due to limited root development, Zinc usability by plants decreases by high levels of phosphorus in the soil, Zinc uptake by plants inhibits by some metal cations such as $\mathrm{Cu}^{2+}$ and $\mathrm{Fe}^{2+}$, (due to the same carriers for these elements in the plant roots) (Chang et al., 2007; Alloway, 2008).

\subsubsection{The Role of Zinc on Enzyme Activities}

Zinc is main building part of some enzymes and is needed for the plant enzymes formation; in addition, many enzymatic reactions active by zinc (Pedler et al., 2000). Zinc plays an important role in most of the enzymes that they can point to the following:

\subsubsection{Zinc Interaction with Phosphorus}

Zinc is active element in biochemical processes and has a chemical and biological interaction with some other elements. Phosphorus is the most important element which interferes on zinc uptake by plants. About the interaction of zinc and phosphorus numerous studies have been done and all confirms this point that zinc and phosphorus imbalance in the plant, As a result excessive accumulation of phosphorus, causing zinc imposed deficiency (Salimpour et al., 2010).

The main reasons for effect of high levels of phosphorus on zinc deficiency can pointed as follows: Zinc transmission of plant roots to shoot reduces by high concentrations of phosphorus, so zinc accumulated in roots or 
its uptake decreases by roots; Zinc concentration in shoots of plants decreases by effect of induced growth response (dilution effect); means that amount of zinc uptake in plant increases by increasing plant growth but its concentration decreases in plant tissues, in other words that element will be diluted in plant tissues; Metabolism defect in plant cells that is related to zinc and phosphorus imbalance, so by increasing the phosphorus concentration, zinc tasks is impaired at specific positions in the cells (Mirvat et al., 2006).

In absence or low concentrations of zinc, phosphorus uptake and transport increased in the shoot and its concentration increased in the leaves, as a result can cause toxicity in the plant. This increase only occurred with zinc deficiency and was not observed in other micronutrient deficiencies; means that zinc deficiency increases the permeability of plasma membrane in root compared to phosphorus (Bukvić1 et al., 2003).

Table 3: Main effect of $\mathrm{Zn}$ and $\mathrm{P}$ fertilization on number of branches, pods plant ${ }^{-1}$, Seeds pod ${ }^{-1}$, plant height $50 \%$ flowering and maturity stage of fababean.

\begin{tabular}{llllll}
\hline Source of variation & PHF & NBS & PPP & SPP & PHM \\
\hline Phosphorus (kg P/ha) & & & & & \\
0 & $39.8^{\mathrm{b}}$ & $0.22^{\mathrm{b}}$ & $4.22^{\mathrm{ab}}$ & $2.78^{\mathrm{b}}$ & $52.98^{\mathrm{c}}$ \\
30 & $41.79^{\mathrm{b}}$ & $0.67^{\mathrm{b}}$ & $4.00^{\mathrm{b}}$ & $2.22^{\mathrm{b}}$ & $60.83^{\mathrm{b}}$ \\
60 & $47.5^{\mathrm{a}}$ & $1.4^{\mathrm{a}}$ & $5.00^{\mathrm{a}}$ & $3.89^{\mathrm{a}}$ & $75.44^{\mathrm{a}}$ \\
SE & 1.46 & 0.23 & 0.345 & 0.474 & 0.155 \\
LSD & 3.1 & 0.48 & 0.732 & 1.004 & 4.411 \\
CV (\%) & 7.2 & 62.5 & 16.6 & 33.9 & 24.00 \\
Zinc (kg Zn/ha) & & & & 2.89 & 62.22 \\
0 & 41.69 & 0.89 & $3.89^{\mathrm{b}}$ & 3.00 & 65.61 \\
15 & 43.13 & 0.67 & $4.56^{\mathrm{ab}}$ & 3.00 & 61.42 \\
25 & 44.27 & 0.78 & $4.78^{\mathrm{a}}$ & 0.474 & 0.155 \\
SE & 1.46 & 0.23 & 0.345 & $\mathrm{NS}$ \\
LSD & $\mathrm{NS}$ & $\mathrm{NS}$ & 0.732 & 33.9 & 24.00 \\
CV (\%) & 7.2 & 62.5 & 16.6 & & $\mathrm{NS}$ \\
\hline
\end{tabular}

Means not connected by the same letters are significantly different at alpha 0.05, NS (non-significant) (Yirga et al., 2012)

Saeed et al (2013) reported that, Zinc and phosphorus fertilizers consumption led to increasing of height, number of tiller, the number of filled grain spike, yield in ha, spike weight in plant, grain length, spike length in $\mathrm{m}^{2}$ and harvest index. According to the results, it was shown that the effect of phosphorus, zinc and their interactive effect on yield and yield components (plant height, tiller number, the number of filled seed in spike, the yield in hectare, the spike weight in plant, seed length, spike length, the number of spike in $\mathrm{m}^{2}$ and harvest index) were significant. The most yields for seed were obtained in $90 \mathrm{~kg}$ phosphorus and $30 \mathrm{~kg}$ zinc consumption in ha. Combined application of different doses of phosphorus and zinc showed significant effect on the plant height, number of branches plant ${ }^{-1}$, number of pods plant ${ }^{-1}$, number of seeds pod $^{-1}$, pod length, weight of 1000-seeds, seed yield and stover yield of mungbean (Rahman et al., 2015).

\subsubsection{Zinc Deficiency and Toxicity in Pants}

Zinc deficiency can be seen in eroded, calcareous and weathering acidic soils. Zinc deficiency is often accompanied with iron deficiency in calcareous soils. Zinc deficiency in these soils is related to adsorption of solution zinc in the soil by clay and limestone particles. In eroded soils, zinc deficiency is caused by organic matter deficiency. Also zinc deficiency may be related to weather conditions, zinc deficiency increases in cold and wet weather conditions. It may be due to the limited root growth in cool soils, or reduction activity of microorganisms and reduction the release of zinc from organic materials (Alam et al., 2010). High concentrations of bicarbonate $\left(\mathrm{HCO}_{3}\right)$ prevent of zinc uptake by plants shoot (Gokhan, 2002).

Zinc deficiency symptoms appear on the young leaves of plants first; because zinc cannot be transferred to younger tissues from older tissue (zinc isn't a mobile element). Areas between nervure in plants are yellow by zinc deficient. In dicot plants internode distance and leaf size will be short and in monocot plants, corn especially, bands comes into the main nervure on both sides of leaves in zinc deficient condition. Overall, shoot is more affected than the root growing by zinc deficiency. When zinc deficiency developed, the yield is more affected than dry matter. This may is due to damage to the pollen fertility by zinc deficiency. The plants that zinc amount in their tissues is lower than $20 \mathrm{ppm}$, are encountered with zinc deficit (Gokhan, 2002).

When zinc amount is excessive, causes toxicity in plants. Leaf and root growth and development decreased by zinc toxicity. Production of NADPH in plant chloroplasts are decreases with increasing zinc concentration. In addition, production of free radicals will increases in plants. Activity of RUBP carboxylase enzyme and Photosystem II decreases by zinc toxicity. Zinc toxicity reduces ATP synthesis and chloroplasts activity and photosynthesis will decline as a result. Also, large amounts of zinc reduces uptake of $\mathrm{P}$ and Fe. More than 300 ppm of zinc in plant caused toxicity. (Prasd et al., 1999). Resistance to zinc is differences in various plants, the plants such as beans, corn, onions, sorghum, rice, citrus fruits and grapes have most sensitivity to zinc deficiency, 
barley, lettuce, potatoes, soybeans, sugar beet and tomato have moderate sensitivity to zinc deficiency and carrots, alfalfa, asparagus, radish, and forage plants are resistance to zinc deficiency (Vitosh et al., 1994).

\subsubsection{The Role of Zinc on Crop Yield and Yield Components}

According to the plant professional's research, zinc exerts a great influence on basic plant life processes, such as: nitrogen metabolism and uptake of nitrogen and protein quality; photosynthesis and chlorophyll synthesis, carbon anhydrase activity; resistance to abiotic and biotic stresses and protection against oxidative damage (Alloway, 2008). Increasing seed concentration of $\mathrm{Zn}$ by soil and/or foliar applications of zinc also brings several agronomic benefits for crop production. Applying zinc to plants grown under potentially zinc-deficient soils is effective in reducing uptake and accumulation of phosphorus (and thus phytate) in plants. This agronomic side effect of zinc fertilization may result in better bioavailability of zinc in the human digestive system. In addition, seedlings from seeds containing high zinc have better ability to withstand adverse environmental conditions. These benefits are discussed in detail below (Mirvat et al., 2006).

Yang and colleagues (2009) in a research reported that the combined application of boron with molybdenum or zinc resulted in higher rapeseed yield and quality than the application of boron with molybdenum or zinc alone, and the seed yield of the $\mathrm{B}+\mathrm{Mo}+\mathrm{Zn}$ treatment was the highest in all treatments. They suggested that optimal micronutrient application could provide both yield and quality advantages for rapeseed in poor soil. Flower yield, essential oil percentage, and essential oil yield in chamomile increased by foliar application of iron and zinc compared with control. It seems that foliar application of iron and zinc can considerably improve flower yield and essential oil content of chamomile especially in calcareous soils (Nasiri, 2010). Maralian, (2009) in another study concluded that foliar application of iron and zinc increased wheat seed yield and its quality compared with control. Zinc concentration in roots and shoots of maize plants were increased by zinc application both in soil and foliar. Regarding the form of application, zinc concentrations in roots and shoots showed a similar trend. The highest zinc doses promoted the maximum zinc concentration in plants both for soil and foliar application (Carolina et al., 2011). The effect of zinc fertilization were conducted on growth and yield of many plants such as alfalfa, wheat, maize, barley and potato were investigated in numerous researches and observed increasing in yield with zinc application ( Shaheen et al., 2007).

Adequate zinc nutrition of alfalfa is essential for good seedling vigour and zinc sufficient plants have better tolerance to water stress and excessive soil moisture content than zinc-deficient plants (Safak, 2009). Also zinc fertilization of alfalfa increased herbage, hay, dry matter crude protein yields and zinc concentration of alfalfa. Eighty per hectare $\left(80 \mathrm{~kg} \mathrm{ha}^{-1}\right)$ zinc treatment provided highest yields (Grewal, 2001). Zinc treated crops were more vigorous than others and had better growth because zinc plays key role in stabilizing RNA and DNA structure, and involves in biosynthesis of growth promoting hormones such as indole 3 acetic acid (IAA) and Gibberellin. Additionally, zinc is an activator of many enzymes involved in photosynthesis, cell elongation and cell division. Thus, yield, crude protein and zinc concentration of Alfalfa significantly affected by zinc fertilization (Safak, 2009).

According to Grace et al.,(2014) the highest grain yield of $3.9 \mathrm{t} \mathrm{ha}^{-1}$ were recorded after combined application of leaf litter and mineral NPK and Zn fertilizer, significantly out yielding than the non-fertilized control the $30 \mathrm{~kg}$ $\mathrm{N} \mathrm{ha}^{-1}+14 \mathrm{~kg} \mathrm{p} \mathrm{ha}^{-1}+\mathrm{Zn}$ treatment by $387 \%$ and $248 \%$ respectively. Application of high rates of $\mathrm{N}$ and $\mathrm{P}$ and $\mathrm{Zn}$ produced $2.5 \mathrm{t} \mathrm{ha}^{-1}$ of maize grain yield compared with $1.6 \mathrm{t} \mathrm{ha}^{-1}$ under the corresponding low fertilizer rates. Figure 1.Residual organic and $\mathrm{Zn}$ fertility effects on maize grain yields following application of inorganic NPK Indicate residual fertility (bars represent SEM). 


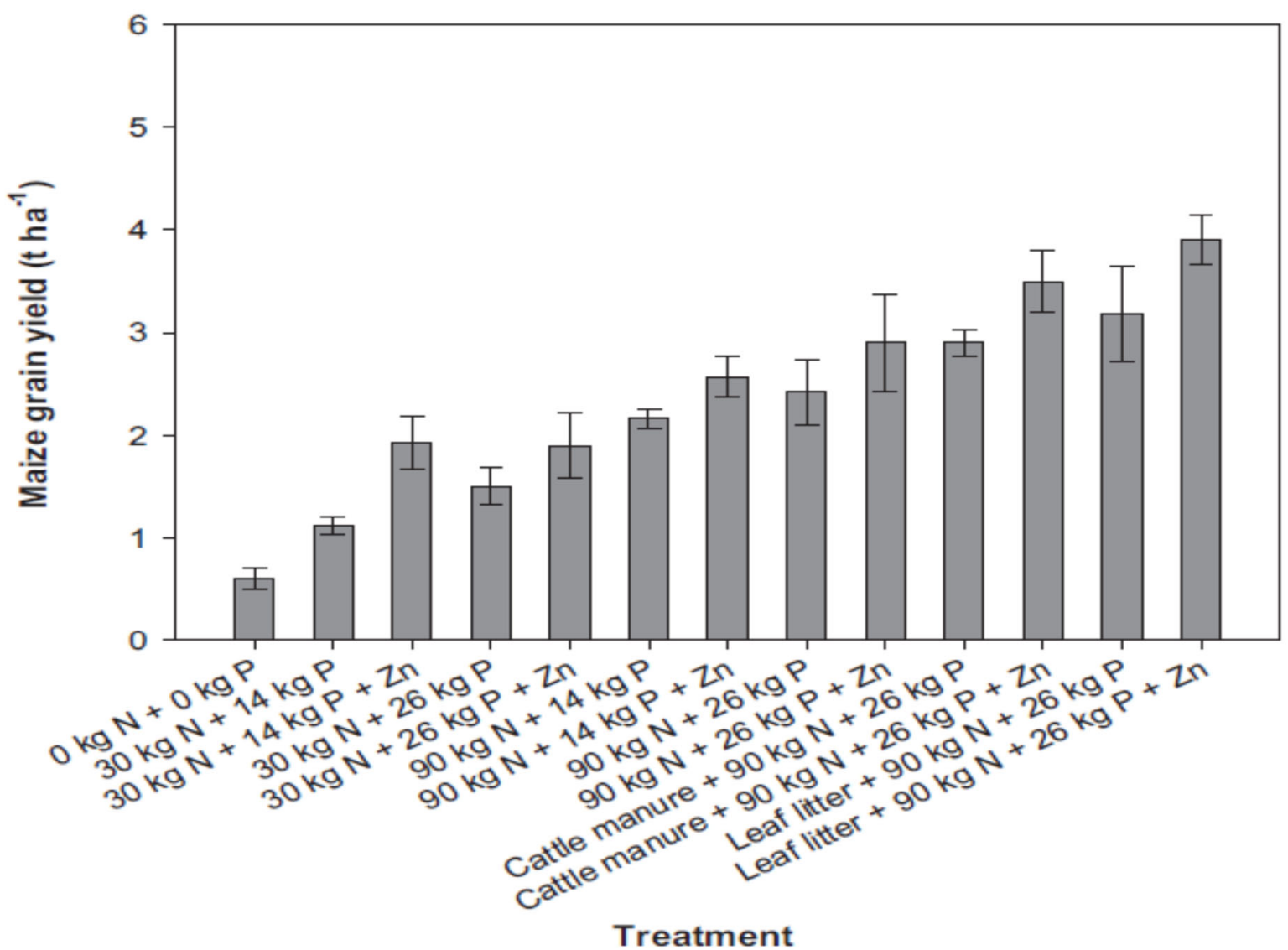

Source: Grace et al (2014)

Ahmad et al., (2015) reported that, the effect of foliar application of zinc fertilizer on the grain yield was not significant. However, application of 0.005 zinc per hectare $(412 \mathrm{~kg} / \mathrm{ha})$ increased the grain yield in comparison to the control treatment. Furthermore, the foliar application of zinc had a significant effect on protein percentage and zinc concentration wheat crop. It seems that foliar application of zinc fertilizer had an effective role in increasing the concentration of grain zinc which was followed by the increase of grain yield.

\section{Summary and Conclusion}

Plant nutrient have significant effects on Yield and yield components, also suitable cultivars and correct consumption of fertilizers lead to optimum uses of soil and environmental factors that produce high yield and yield components. Optimal plant growth requires $\mathrm{P}$ in the range of $0.3-0.5 \%$ of dry matter during the vegetative growth stage. Another very important nutrient is Zinc which is considered as the most limiting micro element in production of crop plant in different parts of the world. The effect of zinc fertilization were conducted on growth and yield of many plants such as alfalfa, wheat, maize, barley and potato were investigated in numerous researches and observed increasing in yield with zinc application.

In general, applications of zinc and phosphorus fertilizers led to increasing yield and yield components of crops such as height, number of tiller, Biomass yield, the number of filled grain spike, yield in ha, spike weight in plant, grain length, spike length in $\mathrm{m}^{2}$ and harvest index etc. Thus, it is important to apply the effect of $\mathrm{P}$ and $\mathrm{Zn}$ nutrients to improve yield and yield components of cops.

\section{Reference}

Ahlawat IPS, Ali M., 1993. Fertilizer Management in pulses; In: Fertilizer management in food crops India: Fertilizer Development and Consultation Organization.; 114-138.

Ahmad N. M., Mojtaba A. F., and Shahram L., 2015. The Effect of Foliar Application of Zinc (Zn) on Yield and Yield Components of Irrigated Wheat Cultivars in Ahvaz Weather Conditions. International Journal of BioSciences/IJB/, ISSN: 2220-6655 (Print), $2222-5234$ (Online) http://www.innspub.net Vol. 6, No. 3, p. 370377.

Alam, M.N., M.J. Abedin, M.A.K. Azad, 2010. Effect of micronutrients on growth and yield of onion under calcareous soil environment, International Research Journal of Plant Science, 1(3) 056-061.

Ali, J., J. Bakht, M. Shafi, S. Khan and W.A. Shah. 2002. Uptake of nitrogen as affected by various combinations 
of nitrogen and phosphorus. Asian Journal of Plant Science, 1: 367-369.

Alloway, B.J., 2008. Zinc in soils and crop nutrition. Second edition, published by IZA and IFA, Brussels, Belgium and Paris, France.

Amsalu, N., Jan, D. and Pascal, B.2016. Phosphorus use efficiency of improved faba bean (Vicia faba L.) varieties in low-input agro-ecosystems. Journal of Plant Nutrition and Soil Science, 179(3): 347-354.

Ayub, M., M.A. Nadeem, M.S. Sharar and N. Mahmood. 2002. Response of maize (Zea mays L.) fodder to different levels of nitrogen and phosphorus. Asian J. P1. Sci. 1: 352-354.

Bagheri A, Nezami A.2000. Effect of weed control and plant densities on yield and morphological characteristics of chickpea in dry farming of north khorasan. Journal of Agricultural Science and industries, Iran.No:14.

Bashir, K., Ali, S. and Umair, A. 2011. Effect of different phosphorus levels on xylem sap components and their correlation with growth variables of mash bean. Sarhad Journal of Agriculture 27(4): 595-601.

Bieleski, R. L., 1973. Phosphate pools, phosphate transport, phosphate availability. Ann Rev Plant Physiology, $24: 225-252$.

Brady, N. C. and R. R Weil, 2002. The Nature and Properties of Soils (13th ed). Pearson education Ltd., USA. pp. 156-198.

Bukvić1, G., M. Antunović, S. Popović, M. Rastija, 2003. Effect of P and Zn fertilisation on biomass yield and its uptake by maize lines (Zea mays L.), Plant Soil Environ, 49(11):505-510. Cakmak, I., 2008. Enrichment of cereal grains with zinc: Agronomic or genetic biofortification? Plant Soil, 302:1-17.

Cakmak I, Yilmaz M, Kalayci M, Torun B, Erenoglu B, Braun HJ (1996). Zinc deficiency as critical problem in wheat production in Central Anatolia. Plant. Soil. 180:165-172.

Carolina, A., F.D. Vasconcelos, C. Williams, A. Nascimento, F.C.F. Fernando, 2011. Distribution of zinc in maize plants as a function of soil and foliar Zn supply. International Research Journal of Agricultural Science, 1(1):001-005.

Chang, W.Y., B.Y. Lu, J.J. Yun, Y.L. Ping, Y. Zheng, X.S. Xin, L.G. An, S. Wei, Z. Chun, 2007. Sufficiency and deficiency indices of soil available zinc for rice in the alluvial soil of the coastal yellow sea. Rice Science, 14(3):223-228.

Chaturvedi, I. 2006. Effects of Different Phosphorus Levels an Growth, Yield and Nutrient Uptake of Wheat (Triticum aestivum L.). International journal of Plant Science, 1(2): 278-281.

Cordell, D., Drangert, J.O., and White, S. 2009. The story of phosphorus: global food security and food for thought. Global Environmental Change 19: 292-305.

Dania Stephen1 O., Ozegbe1 B., Osawe1 G. O. and Michael C. G., 2014. Residual Effect of Phosphorus Fertilizer on Yield of Pigeon Pea (Cajanas cajan) in Ultisol. American Journal of Experimental Agriculture 4(12): 1783-1792.

El-Far, I.A. and B.R. Ramadan, 2000. Response of yield, yield components andseedqualityofpeanut to plant density and PK fertilization in sandy calcareous soil. Proc. 9th Conf. Agron., Minufiya Univ., 1-2 Sept., pp: 453-466.

El-Habbasha, S.F., A.A. Kandil, N.S. Abu-Hagaza, A.K. Abd El-Haleem, M.A. Khalafallah and T.Gh. Behairy,2005. Effect of phosphorus levels and some biofertilizers on dry matter, yield and yield attributes of groundnut. Bull. Fac. Agric., Cairo Univ, 56: 237-252.

FAO (Food and Agriculture Organization), 2000. Fertilizers and their use 4th ed. International fertilizer industry association, FAO, Rome, Italy; FAO Soil Bulletin10.Rome160 pp.

Ghafoor A.M.R., 2016. Effect of Phosphorus Fertilizer Application on Some Yield Components of Wheat and Phosphorus Use Efficiency in Calcareous Soil. Journal of Dynamics in Agricultural Research; Vol. 3(4), pp.46-52, Article ID: JDAR/JDYA42677627, ISSN: 2488-9776. Available online at http://www.journaldynamics.org/jdar.

Giller, K.E. 2001. Nitrogen fixation in tropical cropping systems, 2nd ed. Wallingford, Oxon: CAB International.

Gokhan, H., 2002, Physiological and biochemical mechanisms underlying zinc efficiency in monocot and dicot plants. Plant Physiology, 131: 595-602

Grace M. M., Florence M., Hatirarami N., Paul M., 2014. Zinc Fertilization Influence On Maize Productivity And Grain Nutritional Quality Under Integrated Soil Fertility Management In Zimbabwe.

Grewal, H.S., R. Williams, 2001. Zinc nutrition affects Alfalfa responses to water stress and excessive moisture. Journal of Plant Nutrition, 23(7): 949-962.

Gyaneshwar P, Kumar G.N, Parekh L.J, Poole P.S. 2002. Role of soil microorganisms in improving P nutrition of plants. Plant and Soil, 245: 83-93.

Havlin JL, Tisdale SL, Beaton J, D, Nelson WL (2005). Soil Fertility and Fertilizers-An Introduction to Nutrient Management. 7th edition, Prentice Hall, New Jersey.

Jensen A \& Bro-Rasmussen F (1992) Environmental cadmium in Europe. Rev Environ Contam Toxicol 125: 101180 .

Jiang, Z. Q., Feng, L. L., Huang, W. S., Guo, X., Zhu, K. and Peng, Y. X. 2006. Effects of phosphorus application 
on dry matter production and phosphorus uptake in wheat. Plant Nutrition and Fertility Science, 12(5): 628634.

Kanoni H.2001.Investigation of yield and adaptation in chick pea cultivars in Kordestan. Journal of seed and plant.No:17.

Kasturi K, 1995. Response of Pea to Moisture Stress and Application of P, S and Zn Fertilizers. Ph.D. thesis. Indian Agricultural Research Institute, New Delhi, India. 75-80.

Kumar J, Dhiman S.2004. Moisture stress studies in different chick pea types.www.crop sience.org.au.

Loneragan, J. F. 1978. The physiology of plant tolerance to low P availability, in crop tolerance the sub-optimal land conditions. Jung, G. A., (Ed). American Society of Agronomists, Madison, WI, pp. 329-42.

Maralian, H., 2009. Effect of foliar application of $\mathrm{Zn}$ and Fe on wheat yield and quality. African Journal of Biotechnology, 8 (24): 6795-6798.

Marschner, H., 1993. Zinc Uptake from Soils. In Zinc in Soils and Plants, Robs on, A,D., Ed.,Kluwer Academic publishers, Dordrecht, The Netherlands, pp: 59-77.

Mesfin Kassa, Zemach Sorsa, 2015. Effect of Nitrogen and Phosphorus Fertilizer Rates on Yield and Yield Components of Barley (Hordeum Vugarae L.) Varieties at Damot Gale District, Wolaita Zone, Ethiopia. American Journal of Agriculture and Forestry. Vol. 3, No. 6, 2015, pp. 271-275. doi: 10.11648/j.ajaf.20150306.15

Miressa D, RoBarge WP (1999). Soil characteristic and management effects on phosphorous sorption by high land plateau soils of Ethiopia. Soil Science Society of American Journal, 63:1555-1462.

Mirvat, E.G., M.H. Mohamed, M.M. Tawfik, 2006. Effect of phosphorus fertilizer and foliar spraying with zinc on growth, yield and quality of groundnut under reclaimed sandy soils. Journal of Applied Science Research, 2(8): 491-496.

Mousavi, S.R., M. Galavi, G. Ahmadvand, 2007. Effect of zinc and manganese foliar application on yield, quality and enrichment on potato (Solanum tuberosum L.). Asian Journal of Plant Sciences, 6: 1256-1260.

Moustakas, N.K., A.I. Akoumianaki, P.E. Barouchas, 2011. The effects of cadmium and zinc interactions on the concentration of cadmium and zinc in pot marigold (Calendula officinalis L.). Australian Journal of Crop Science, 5(3): 277-282.

Mwalwanda, A.B., Mughogho, S.K., Sakala, W.D. and Saka, A.R. 2003. The effect of phosphorus and sulphur on green manure legume biomass and the yield of subsequent maize in northern Malawi. In: Waddington SR (ed.) Grain Legumes and Green Manures for Soil Fertility in Southern Africa. Proceedings of a conference held 8-11 October 2002 at the Leopard Rock Hotel, Vumba, Zimbabwe. Harare, Zimbabwe: Soil Fertility Network and CIMMYT-Zimbabwe. pp. 197-204.

Nasiri, Y., S.S. Zehtab, S. Nasrullahzadeh, N. Najafi, K. Ghassemi, 2010. Effects of foliar application of micronutrients ( $\mathrm{Fe}$ and $\mathrm{Zn}$ ) on flower yield and essential oil of chamomile (Matricaria chamomilla L.) Journal of Medicinal Plants Research, 4(17): 1733-1737.

Nasr-Alla, A.E., A.A. Osman Fatma and K.G. Soliman, 1998. Effect of increased phosphorus and potassium or sulfur application in their different combinations on yield, yield components and chemical composition of Peanut in a newly reclaimed sand soil. Zagazig Journal Agricultural Research, 25: 557-579.

Nisar A. 1985. Phosphorus requirement of wheat crops in different cropping system. Fert. News. 30: 38-42.

Pedler, J.F., D.R. Parker, D.E. Crowley, 2000. Zinc Deficiency-induced phytosiderophore release by the Triticaceae is not consistently expressed in solution culture. Planta, 211: 120-126. Austiralian Journal of Basic \& Applied Science, 5(9): 1503-1509, 2011.

Pramanik MYA, Sarkar MAR, Uddin MS, Faruk GM.,2009. Effects of phosphorus on growth, nodulation and biomass yield of green manure crop. Journal of Bangladesh Agricultural University. 7(1):23-28.

Prasd, K., P.P. Saradhi, P. Sharmila, 1999. Concerted action of antioxidant enzymes and curtailed growth under zinc toxicity in Brassica juncea. Environmental and experimental Botany, 42: 1-10.

Rahman M. M., Adan M. J., Chowdhury M. S. N., Ali M. S. and Mahabub T. S., 2015. Effects of Phosphorus and Zinc on the Growth and Yield of Mungbean (BARI mug 6). International Journal of Scientific and Research Publications, Volume 5, Issue 2, ISSN 2250-3153.

Rao, I.M., Friesen, D.K. and Osaki, M. 1999. Plant adaptation to phosphorus-limited tropical soils. In: Pessarakli, M. (ed.). Handbook of Plant and Crop Stress, Madison Avenue, New York: Marcel Dekker, 1999. pp. 61-96

Rose T. J. and Wissuwa, M. 2012. Rethinking internal phosphorus utilization efficiency: A new approach is needed to improve PUE in grain crops. Advanced Agronomy, 116: 185-217.

Saeed M., Seyyed M. S., and Hamidreza D., 2013. Effect of Zinc and Phosphorus Fertilizers on Yield and Component Yield of Rice (Hashemi). Persian Gulf Crop Protection. Available online on: www.cropprotection.ir ISSN: 2251-9343 (online) Vol. 2. Pp. 30-36

Safak, C., S. Hikmet, B. Bülent, A. Hüseyin, C.E. Bihter, 2009. Effect of zinc on yield and some related traits of alfalfa. Turkish Journal of Field Ctops, 14(2): 136-143

Salimpour, S., K. Khavazi, H. Nadian, H. Besharati, M. Miransari, 2010 Enhancing phosphorous availability to 
canola (Brassica napus L.) using P solubilizing and sulfur oxidizing bacteria. Australian Journal of Crop Science, 4(5): 330-334.

Sara, S., Morad, M. and Reza, C.M. 2013. Effects of seed inoculation by Rhizobium strains on chlorophyll content and protein percentage in common bean cultivars (Phaseolus vulgaris L.). International Journal of Biosciences, 3: 1-8.

Seid H, Fikrte Y.,and Fetelwork T., 2015. Effect of Phosphorus Fertilizer on Yield and Yield Components of Chickpea (Cicer Arietinum) at Kelemeda, South Wollo, Ethiopia. International Journal of Agricultrural Extension and Rural Development Studies, Vol.1,No.1,pp.29-35

Shaheen, R., M.K. Samim, R. Mahmud, 2007. Effect of zinc on yield and zinc uptake by wheat on some soils of Bangladesh. Journal of Soil Nature, 1(1): 07-14.

Sharpley, A.N. 2000. Dependence of runoff phosphorus on soil phosphorus. Journal of Environmental Quality, 24:920-926.

Shuman LM (1988) Effect of phosphorus level on extractable micronutrients and their distribution among soil fractions. Soil Science Society of American Journal, 52: 136-141.

Singh BR (1994) Trace element avilability to plants in agricultural soils with special emphasis on fertilizer inputs. Environ Rev 2: 133-146.

Soler Soler J \& Soler Rovita J (1996) Cadmium in inorganic fertilizers. In: Rodrigues-Barrueco C (ed) Fertilizers and Environment, pp 541-545. Kluwer Academic Publishers, The Netherlands

Tariq M., Rozina G., F.,M., Fazal J., Zahid H., Nadia N., Hamayoon K., N., And Hayatullah K., 2011. Effect of Different Phosphorus Levels on the Yield and Yield Components of Maize. Sarhad Journal of Agriculture. Vol.27, No.2.

Togay, N., Togay, Y.,Cimrin, K. M. and Turan, M. 2008. Effects of Rhizobium inoculation sulfur and phosphrus applications on yield, yield components and nutrient uptakes in chickpea (Cicer arietinum L.). African Journal of Biotechnology, 7:776-782.

Toro, M., Azcón, R. and Barea, J.M. 1998. The use of isotopic dilution techniques to evaluate the interactive effects of Rhizobium genotype, mycorrhiza fungi, phosphate-solubilizing rhizobacteria and rock phosphate on nitrogen and phosphorus acquisition by Medicago sativa. New Phytologist, 138: 265-273.

Tsvetkova, G.E. and Georgiev, G.I. 2003. Effects of phosphorus nutrition on the nodulation, nitrogen fixation and nutrient use efficiency of Bradyrhizobium japonicum Soybean (Glycine max L. Merr.) Symbiosis. Bulgarian Journal of Plant Physiology. Special Issue 331-335.

Uchida, R. 2000. Essential nutrients for plant growth: Nutrient functions and deficiency symptoms. Plant nutrient management in Hawaii's soils. College of Tropical Agriculture and Human Resources, University of Hawaii: $31-55$.

Vance, C.P., Uhde-Stone, C. and Allan, D.L. 2003. Phosphorus acquisition and use: critical adaptations by plants for securing a nonrenewable resource. New Phytologist, 157: 423-447.

Vitosh, M.L., D.D. Warncke, R.E. Lucas, 1994. Zinc determine of crop and soil. Michigan State University Extension.

Yamane A, Skjelvåg OA (2003). Effects of fertilizer phosphorus on yield traits of Dekeko (Pisum sativum var. abyssinicum) under field conditions. Journal of Agronomy Crop Science, 189:14-20.

Yirga, W. Mitiku H., and Kiros H., (2012). Effect of zinc and phosphorus fertilizers application on yield and yield components of faba bean (Vicia faba L.) grown in calcaric cambisol of semi-arid northern Ethiopia. Journal of Soil Science and Environmental Management, Vol. 3(12), pp. 320-326, Available online at: http://www.academicjournals.org/JSSEM DOI: 10.5897/JSSEM12.062, ISSN 2141-2391. 